\title{
EVALUATION OF THIOREDOXIN-1 SERUM MARKER FOR EARLY DIAGNOSIS OF PRIMARY BREAST CANCER
}

\author{
DHIA J. AL-TIMIMI1, BSc (Pharm), MPhil, PhD * \\ DANIA Y. HUSSEIN, BSc, MSc** \\ SHERWAN F. SALIH1, MBChB, FIBMS *** \\ INTISAR S. PITY, MBChB, MSc, FIBMS ****
}

\section{Submitted 4/11/2017; accepted 31/12/2017}

\begin{abstract}
Background: Serum thioredoxin-1 (TRX-1) may be a useful biomarker for early diagnosis of breast cancer.

Subject and Methods: Thioredoxin -1 and cancer antigen15-3 levels were determined using Enzyme-Linked Immunosorbent Assay (ELISA) in 141 women: 55 had primary breast cancer, 35 with benign breast tumor and 51 were apparently healthy controls matched for age, waist circumference and body mass index. Diagnosis involved all women with breast mass who referred to the Histopathology Department, Duhok Specialized laboratory Center during the study period. Fine needle aspirate (FNA) cytology test was carried out first and then the findings were later on compared with histological results to confirm the diagnosis. Breast cancer women were further grouped into subtypes based on immunohistochemistry. The aim of this study was to assess the diagnostic capacity of thioredoxin-1 for primary breast cancer.
\end{abstract}

Results: Significantly higher Thioredoxine -1 and cancer antigen $15-3$ levels $(\mathrm{p}=0.001$ and $\mathrm{p}=0.011$ respectively) were found in primary breast cancer group compared to benign breast tumor group and healthy women. In breast cancer group, positive test was observed 2 times more likely than in benign breast tumor group as well in healthy women, with a sensitivity of 94.5\%, specificity $72.1 \%$ and Receiver Operating Characteristics Curve ROC 0.872. Totally different and less significant values were observed for cancer antigen $15-3$, sensitivity $16.4 \%$, specificity 93.0\% and Receiver Operating Characteristics Curve ROC 0.352.

Conclusions: Elevated thioredoxin-1 level in conjunction with a high sensitivity and specificity may be strongly associated with primary breast cancer in women; this may indicate the needs for determining serum thioredoxin-1 as a screening test for early diagnosis of primary breast cancer

Duhok Med J 2017; 11 (2): 19-26.

Keywords: Breast cancer, Thioredoxin-1, Cancer antigen 15-3, Healthy women.

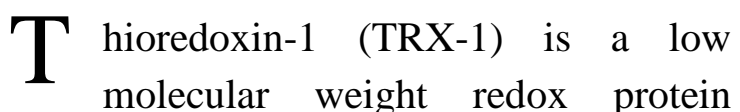
found in both prokaryotic and eukaryotic cells $^{1 .} \quad$ It activates specific nuclear transcription factors involved in gene decoding for production of substances that protect cells from oxidative stress induced by free oxygen radicals ${ }^{2}$. It has been proposed that serum TRX-1 may be a useful biomarker for early prediction of breast cancer, and higher levels have been found in sera of breast cancer patients ${ }^{3}$. An increase in the level of TRX-1 has been found to be associated with decreased

* Professor., Department of Medical Chemistry, College of Medicine, University of Duhok, Kurdistan Region, Iraq.

** Assist. lecturer, Department of Medical Chemistry, College of Medicine, University of Duhok, Kurdistan Region, Iraq.

*** Assist. Prof., Department of Medical Chemistry, College of Medicine, University of Duhok, Kurdistan Region, Iraq.

**** Professor., Department of Pathology, College of Medicine, University of Duhok, Kurdistan Region, Iraq.

19

Correspondence author to: Dhia J.Al-Timimi, altmimidj@yahoo.com, Mobil +9647504228908 
survival in tumor patients and is used as independent prognostic factor for the progression and expression of vascular endothelial growth factor and redox factor$1^{4}$. Due to the early detection, it is important to search and assess such emerging biomarkers for breast cancer diagnosis. Therefore, the present study was carried out to assess the diagnostic capacity of TRX-1 for primary breast cancer.

\section{PATIENTS AND METHODS}

\section{Subjects and Study Design:}

This prospective cross-sectional study was conducted at Duhok Specialized Histopathology Centers, Kurdistan region, Iraq from December 2015 until May 2016. Ninety women (ages 35-61 years) who had breast mass and fifty one healthy women matched for age, waist circumference and body mass index were enrolled in the study. Diagnoses were primarily got by Fine needle aspirate (FNA) cytology test and later on confirmed by histological findings .Breast cancer women were further grouped into subtypes based on expression of estrogen receptors, progesterone receptors, Her 2//neu enriched, triple negative and triple positive by immunohistochemistry results. Exclusion criteria included women with secondary breast cancer and healthy women with family history of breast cancer. The study plan was approved by the Research Ethic-committee, Duhok Directorate of health, and written informed consent was signed by each woman in the study.

\section{Laboratory measurements:}

Phlebotomy was performed in the morning, after a medical examination.
Blood samples were collected for biochemical tests including Serum TRX-1 and cancer antigen15-3(CA 15-3) levels. An indirect ELISA (Enzyme-linked immunosorbent assay) was performed to quantitatively analyze the level of TRX-1

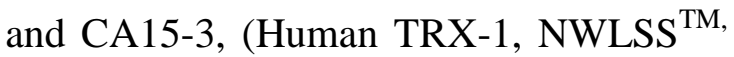
NWK-TRx01and CA15-3, Roche Diagnostic GmbH, D-68305 Mannheim, Germany.

\section{Anthropometric Measurements:}

Anthropometric measurements-body height $(\mathrm{cm})$, body weight $(\mathrm{kg})$ and waist circumference (WC) in cm were obtained. Body mass index (BMI) was calculated as weight in kilograms divided by height in meters squared.

Statistical Analyses: Data were analyzed using the statistical package for Social Sciences (SPSS) version 21(USA). Independent t-test was used to assess differences in serum analyte among groups. Categorical variables were analyzed by Chi-square tests. Power analysis was performed for TRX-1 and CA15-3 with values exceeding 0.90.ROC analysis was used to evaluate the sensitivity and specificity of TRX-1 and CA15-3.

\section{RESULTS}

Table 1 shows the baseline characteristics of women with primary breast cancer, benign breast tumor and healthy controls. No significant differences were found with respect to age, WC and BMI between breast cancer groups and controls. Significantly higher CA15-3 and TRX-1 levels were observed in women with breast cancer group compared to controls ( $p=0.011$ and $p=0.001$, respectively). 
A significant higher mean TRX-1 level (almost 2 times higher) was found in the breast cancer group compared with benign group $(p=0.01)$.

\begin{tabular}{ccccc}
\hline \multicolumn{5}{c}{ Table 1: Baseline Characteristics of studied women } \\
\hline Characteristics & Controls & Benign Tumor & Breast Cancer & $p$-value* \\
& $(\mathrm{n}=51)$ & $(\mathrm{n}=35)$ & $(\mathrm{n}=55)$ & \\
\hline Age(years) & $38.6 \pm 8.5$ & $40.8 \pm 12.3$ & $43.9 \pm 11.8$ & 0.188 \\
WC $(\mathrm{cm})$ & $92.4 \pm 16.9$ & $95.5 \pm 18.6$ & $95.6 \pm 16.0$ & 0.306 \\
BMI $\left(\mathrm{kg} / \mathrm{m}^{2}\right)$ & $31.2 \pm 7.2$ & $32.3 \pm 9.3$ & $32.9 \pm 8.1$ & 0.252 \\
CA-15.3(U/ml) & $18.4 \pm 7.1$ & $15.1 \pm 5.5$ & $25.1 \pm 16.9$ & 0.011 \\
TRX-1 $(\mathrm{U} / \mathrm{ml})$ & $49.5 \pm 39.1$ & $55.7 \pm 41.0$ & $120.5 \pm 63.1$ & 0.001 \\
\hline
\end{tabular}

Results: mean \pm SD,

*Breast cancer vs. controls

Parameters from ROC analysis on serum CA15-3 and TRX-1 levels between women with breast cancer and controls are presented in Table 2 and Figure 1.
When the serum TRX-1 was measured in breast cancer women in comparison with healthy women, the area under curve

Table 2: Parameters from ROC analysis on serum CA15-3 and TRX-1 levels in women with breast cancer/healthy controls

\begin{tabular}{ccccc}
\hline & AUC+SEM & Asymptomatic 95\% CI & Sensitivity\% & Specificity\% \\
CA15-3 & $\mathbf{0 . 3 5 2} \pm \mathbf{0 . 0 4 7}$ & $\mathbf{0 . 2 6 - 0 . 4 4 3}$ & $\mathbf{1 6 . 4}$ & $\mathbf{9 3 . 0}$ \\
TRX-1 & $\mathbf{0 . 8 7 2} \pm \mathbf{0 . 0 2 9}$ & $\mathbf{0 . 8 1 4 - 0 . 9 2 9}$ & $\mathbf{9 4 . 5}$ & $\mathbf{7 2 . 1}$ \\
\hline
\end{tabular}

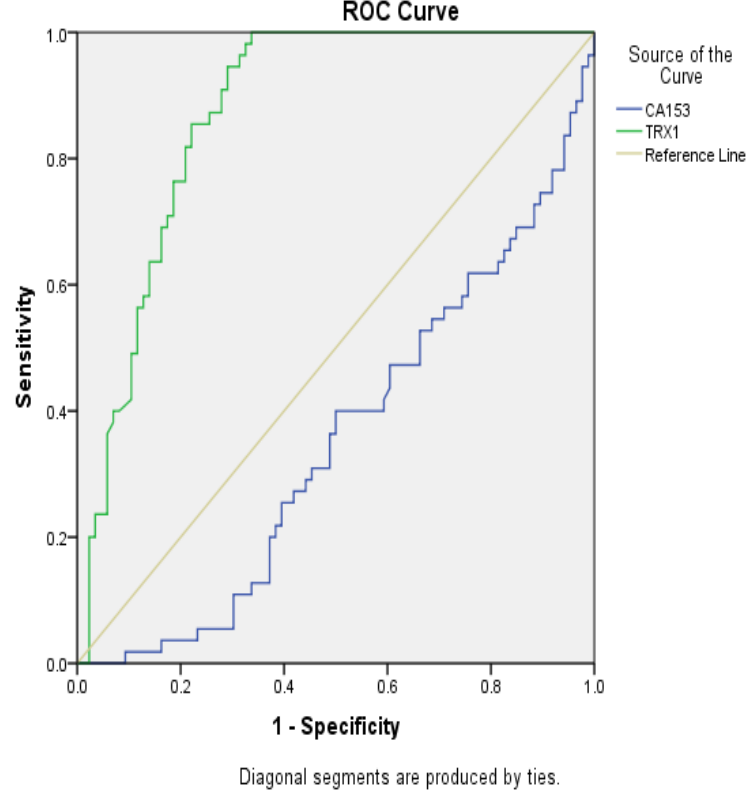

Figure 1. ROC analysis of Trx-1 and CA15.3 in primary breast cancer group
(AUC) value exceeded about 0.87 , with the sensitivity and specificity detected more than $94 \%$ and $72 \%$ respectively. Regarding CA15-3 the AUC value was around 0.35 , which failed to show a statistically significant difference from the 0.5 area of an equivocal test.

Analysis of the breast cancer-healthy differences in rate of positive (abnormal) results of TRX-1 and CA15-3 are summarized in Table 3. As shown, the true negative group determined by the cutoff value of TRX-1 (60.5 U/ml) was $59(68.6 \%)$ and false positive $27(31.4 \%)$, while the true positive group 53(96.4\%) and false negative 2(3.6\%).The true negative group determined by the cut-off 
value of CA15-3 (35 U/ml) was 80(93.0\%) and false positive $6(7.0 \%)$, while the true positive group $9(16.4 \%)$ and false negative $46(83.6 \%)$.

Table 3: Reality of breast cancer-healthy differences in rate of positive TRX-1 \& CA15-3

\begin{tabular}{cccc}
\hline \multicolumn{4}{c}{ Reality } \\
\hline TRX-1, n (\%) & Negative & Positive & Total \\
\hline Negative & $59(68.6)$ & $2(3.6)$ & $61(43.3)$ \\
Positive & $27(31.4)$ & $53(96.4)$ & $80(56.7)$ \\
CA15-3, n(\%) & & & \\
Negative & $\mathbf{8 0}(93.0)$ & $46(83.6)$ & $126(89.4$ \\
Positive & $6(7.0)$ & $9(16.4)$ & $15(10.6)$ \\
\hline
\end{tabular}

To determine the usefulness of TRX-1 as a companion marker to CA15-3 as a screening test for primary breast cancer, we calculated its validity with regard to cut-off point of CA15-3 (35 U/ml).The diagnosis of breast cancer with the cut-off value of TRX-1(60.5 U/ml) was associated with a higher sensitivity $(90.8 \%)$ compared to CA15-3 (9.2\%), $p=0.001$ (Table 4).

\begin{tabular}{ccccc}
\hline Table 4: Comparison of TRX-1 with CA15-3 as \\
\multicolumn{5}{c}{ a breast cancer marker } \\
\hline CA15-3 & $\begin{array}{c}<35 \\
\mathrm{U} / \mathrm{ml}\end{array}$ & $\begin{array}{c}\geq 35 \\
\mathrm{U} / \mathrm{ml}\end{array}$ & Total & $\begin{array}{c}p- \\
\text { value }\end{array}$ \\
\hline $\begin{array}{c}\text { TRX- } \\
\text { 1(U/ml), }\end{array}$ & $\mathbf{n}(\%)$ & $\mathrm{n}(\%)$ & $\mathrm{n}(\%)$ & \\
\hline$<60.5$ & $5(3.5)$ & $60(42.6)$ & $65(46.1)$ \\
& & & & \\
$\geq 60.5$ & $8(5.7)$ & $68(48.2)$ & $76(53.9)$ & 0.001 \\
Total & $13(9,2)$ & $128(90.8)$ & $141(100)$ & \\
\hline
\end{tabular}

The mean of serum TRX-1 and CA15-3 of Subtypes of breast cancer women are presented in Table 5. No significant differences were observed with respect to immunohistochemistry results among the subgroups.

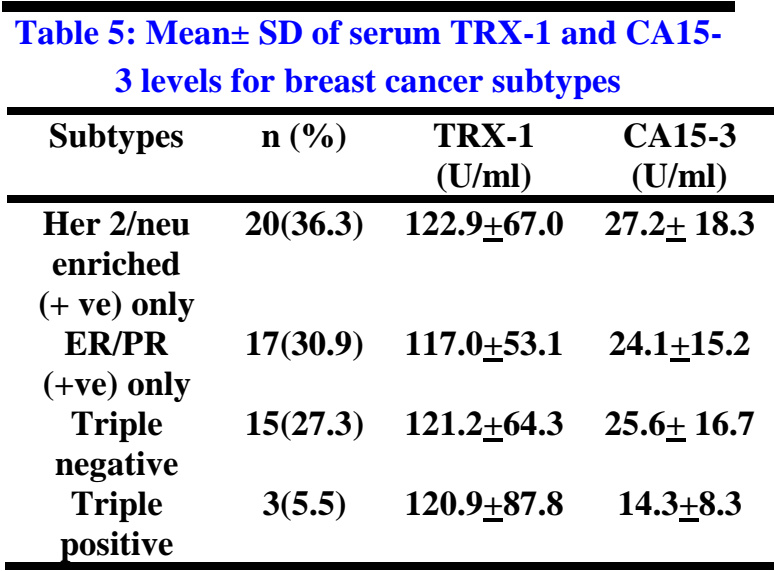

\section{DISCUSSION}

The results of this study showed significantly higher TRX-1 levels in women with breast cancer compared with levels in healthy women as well as in women with benign breast tumor. The results confirm a higher sensitivity of TRX-1 than that of CA15-3, as the mean TRX-1 level observed in breast cancer women was 2 times higher than that observed in controls and women with benign breast tumor. These results are in accordance with previous studies ${ }^{5,} 6$. Moreover, the current study reported nearly similar TRX-1 values in healthy women and benign group, suggesting that a different mechanism, other thanTRX-1 may involve benign tumorgenesis. The mechanism through which the TRX-1 play a role in the apoptosis has been suggested by many researchers ${ }^{7}$, oxidative stress, a characteristics feature of many cancers including the breast cancer, has been implicated in the cancer development and progression $^{8}$. One of the most important cellular cytoplasmic redox system is the Thioredoxine system encompassed TRX-1, TRXR1 and $\mathrm{NADPH}^{9}$. It has a high expression in many cancer cells, including breast tumor ${ }^{10}$. TRX-1 can act as a direct scavenger of ROS, and reduced form 
inhibits apoptosis by binding to apoptosis signal regulating kinase -1 (ASK-1) ${ }^{11,12}$. An association between the high level of TRX-1 expression and aggressiveness of tumors in human cancer involving breast cancer has been also argued by others ${ }^{13}$. However, none of the mentioned reports directly related any evidence of TRX-1 expression in benign breast tumor. It is interesting to note that when the serum TRX-1 was measured in breast cancer women in comparison with healthy women, the AUC (area under curve) value exceeded about 0.872 , with the sensitivity and specificity detected more than $94 \%$ and $72 \%$ respectively. The global study by Park et, al. ${ }^{3}$ also reported a high values of sensitivity $89.0 \%$, specificity $78.0 \%$ and AUC 0,901.

Our results suggest an important capacity for the early detection of breast cancer through TRX-1 measurements, although, the TRX-1 levels in the other relevant carcinomas has not been determined, which is a limitation of this study. This might underestimate the definitive conclusion regarding the role of TRX-1 specifically related to these patients with breast cancer. The drawback of the current study includes the lower sample size to evaluate the relationship between serum level of TRX-1 and tumor cells expression of estrogen receptor, progesterone receptor or Her2/ neu enriched. Therefore further studies considering these aspects may be necessary in the women with breast cancer.

Comparison of breast cancer with benign breast tumor and healthy controls women showed that the highest TRX-1 levels with its high sensitivity and specificity were detected in blood taken from breast cancer women. In addition we suggest that the capacity of TRX-1 for the early detection of breast cancer is higher than that of CA15-3, especially regarding sensitivity. The elevated thioredoxin-1 level in conjunction with a high sensitivity and specificity in women with breast cancer suggesting TRX-1 is strongly associated with primary breast cancer; this may indicate the needs for determining serum thioredoxin-1 as a screening test for early diagnosis of breast cancer.

\section{ACKNOWLEDGEMENT}

This work was supported by the College of Medicine, University of Duhok.

\section{REFERENCES}

1. Cromer S, Urig S, Becker $\mathrm{K}$. Thioredoxine system-from science to clinic. Med Res Rev. 2004; 24(1):4089.

2. Shi Q, Gibson GE. Oxidative stress and transcriptional regulation in Alzheimer's disease. Alzheimer Dis Assoc Disord. 2007; 21(4):276-91.

3. Park B, Cha M, Kim I. Thioredoxin-1 as a serum marker for breast cancer and its use in combination with CEA or CA15-3 for improving the sensitivity of breast cancer diagnoses. BMC Res Notes. 2014; 7:7.

4. Welsh S, Bellamy W, Briehl M, Powis G. The redox protein thioredoxin-1 (TRX-1) increases hypoxia-inducible factor 1 alpha protein expression: TRX-1 overexpression results in increased vascular endothelial growth factor production and enhanced tumor angiogenesis. Cancer Res. 2002; 62:5089-95. 
5. Cha MK, Suh KH, Kim IH. Overexpression of peroxiredoxin 1 and thioredoxin 1 in human breast carcinoma.Exp Clin Cancer Res. 2009; 28:93-101.

6. Cha MK, Park BJ, Kim II H. Thioredoxin 1 as a novel serum marker for human ovarian cancer. The FASEB journal 2012;26(I Supp 967.5).

7. Arner ES, Holmgren A. The thioredoxin system in cancer. Semin Cancer Biol. 2006; 16:420-6.

8. Reuter S, Gupta S, Chaturvedi M, Aggarwal B. Oxidative stress, inflammation, and cancer:: how are they linked?. Free Radic Biol Med. 2010; 49(11):1603-16.

9. Holmgren A, Lue J. Thioredoxin and thioredoxin reductase: current research with special reference to human disease.Biochem Biophys Res Commun. 2010; 396(1):120-4.

10. Lincoln DT, Emadi FM, Tonissen KF, Clarke FM. The thioredoxin reductase system: over expression in human cancer. Anticancer Res. 2003;23: 2425-33.

11. Das KC, Das CK. Thioredoxin a single to oxygen quencher and hydroxyl radical scavenger: redox independent finctions. Biochem Biophys Res Commun. 2000; 277(2); 443-7.

12. Ueda S, Masutani H, Nakamura H, Tanaka T, Uneo M, Yodoi J. Redox control of cell death. Antioxid Redox Signal. 2002(3); 4:405-14.

13. Lillig $\mathrm{CH}$, Holmgren A. Thioredoxin and related molecules: from biology to health and disease. Antioxid Redox Signal. 2007; 9(1):25-47. 


\section{توختة}

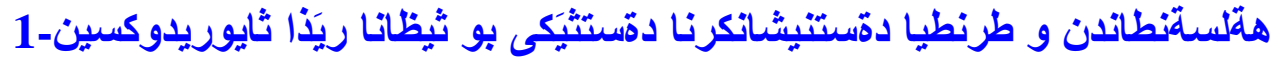

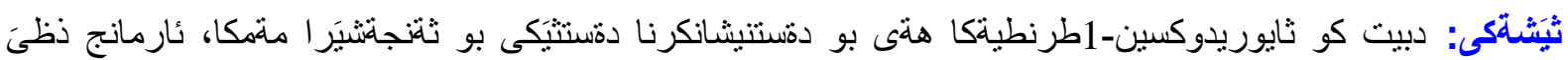

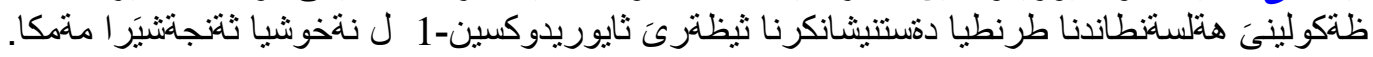

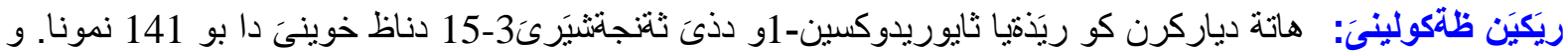

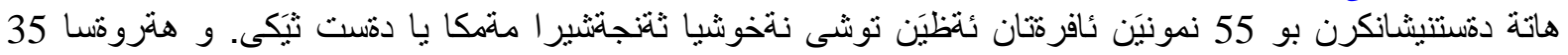

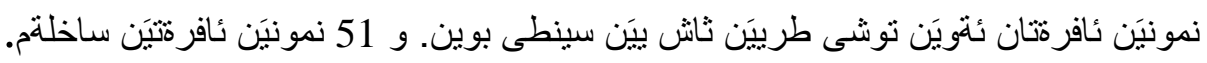

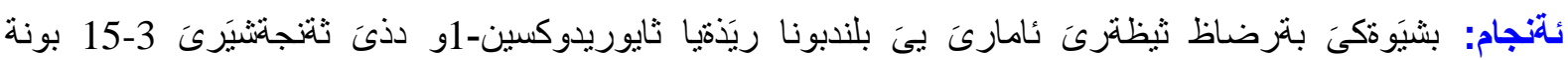

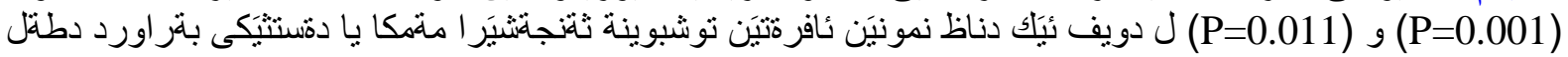

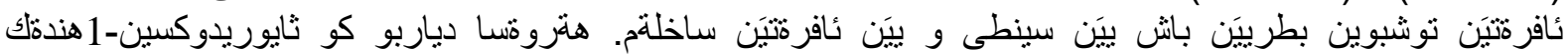

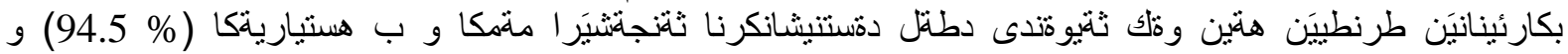

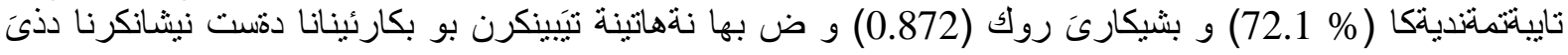

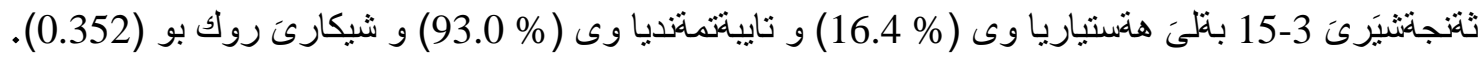

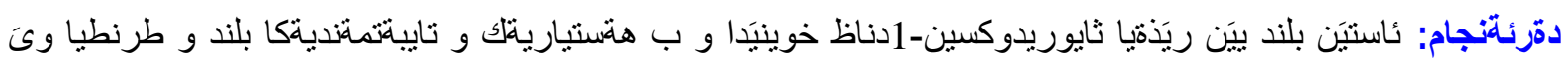
بو دةتنتيشانكرنا نةخوشيا ثنتجنتشيَر ا مةمكا. 


\section{الخلاصة}

\section{تقييم الأهمية التثخيصية المبكرة لمستوى الثايوريدوكسين -1}

الخلفية والأهداف: ان الثايوريدوكسين-1 له أهمية تثخيصية مبكرة لسرطان الثذي والهدف من هذه الدراسة تقييم الاهمية التشخيصية لدالة الثايوريدوكسين -1 في سرطان الثائي.

طرق البحث: لقد تم تحديد مستويات الثايوريدوكسين-1 ومستضد السرطان 3-15 في مصل 141 عينة. حيث تم تثخيص 55 عينة لاناث مصابات بسرطان الثي الابتدائي، و 35 عينة لاناث مصابات بأورام الثي الحميدة و 51 الثان

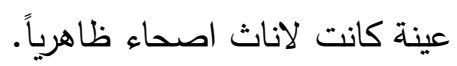

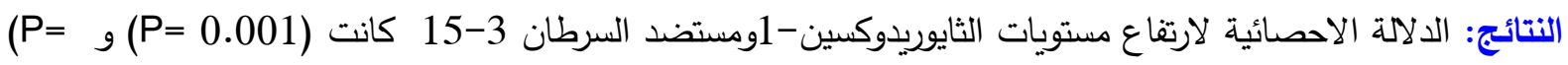

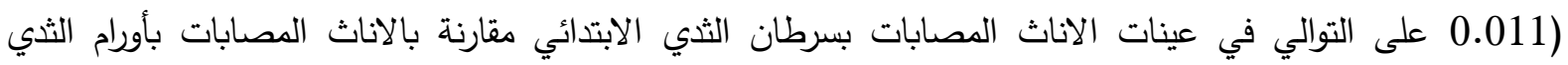
الحميدة والاناث الاصحاء. لوحظ أن الثايوريدوكسين-11 له استخدامات قيمة كعلاقة تثخيصية لسرطان الثاني وبحساسية (94.5 ) وخصوصية (72.1\%) وتحليل روك (0.872). ولم يلاحظ أي قيمة تثخيصية في استخدام مستضد السرطان (3-15). وان الحساسية كانت (16.4\%) والخصوصية (72\% وت (93.0) وتحليل روك كان (0.852).

الاستتاج: ارتفاع مستوى الثايوريدوكسين-1 في مصل الدم مصحوب بحساسية وخصوصية عالية وله اهمية تشخيصية

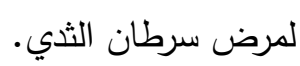

